\title{
Aquaporins (version 2020.4) in the IUPHAR/BPS Guide to Pharmacology Database
}

\author{
Roslyn Bill ${ }^{1}$, Alex C. Conner ${ }^{2}$, Philip Kitchen ${ }^{1}$ and Mootaz Salman ${ }^{3}$ \\ 1. Aston University, UK \\ 2. University of Birmingham, UK \\ 3. Harvard Medical School, USA
}

\begin{abstract}
Aquaporins and aquaglyceroporins are membrane channels that allow the permeation of water and certain other small solutes across the cell membrane, or in the case of AQP6, AQP11 and AQP12A, intracellular membranes, such as vesicles and the endoplasmic reticulum membrane [17]. Since the isolation and cloning of the first aquaporin (AQP1) [21], 12 additional mammalian members of the family have been identified, although little is known about the functional properties of one of these (AQP12A; Q8IXF9) and it is thus not tabulated. The other 12 aquaporins can be broadly divided into three families: orthodox aquaporins (AQP0,-1,-2,-4,-5, -6 and -8 ) permeable mainly to water, but for some additional solutes [5]; aquaglyceroporins (AQP3,-7 -9 and -10), additionally permeable to glycerol and for some isoforms urea [16], and superaquaporins (AQP11 and 12) located within cells [14]. Some aquaporins also conduct ammonia and/or $\mathrm{H}_{2} \mathrm{O}_{2}$ giving rise to the terms 'ammoniaporins' ('aquaammoniaporins') and 'peroxiporins', respectively. Aquaporins are impermeable to protons and other inorganic and organic cations, with the possible exception of AQP1 [16]. One or more members of this family of proteins have been found to be expressed in almost all tissues of the body [reviewed in Yang (2017) [27]]. AQPs are involved in numerous processes that include systemic water homeostasis, adipocyte metabolism, brain oedema, cell migration and fluid secretion by epithelia and loss of function mutations of some human AQPs, or their disruption by autoantibodies further underscore their importance [reviewed by Verkman et al. (2014) [24], Kitchen et al. (2105) [16]].

Functional AQPs exist as homotetramers that are the water conducting units wherein individual AQP subunits (each a protomer) have six transmembrane helices and two half helices that constitute a seventh 'pseudotransmembrane domain' that surrounds a narrow water conducting channel [17]. In addition to the four pores contributed by the protomers, an additional hydrophobic pore exists within the center of the complex [17] that may mediate the transport of gases (e.g. $\mathrm{O}_{2}, \mathrm{CO}_{2}, \mathrm{NO}$ ) and cations (the central pore is the proposed transport pathway for cations through AQP1) by some AQPs [8, 15]. Although numerous small molecule inhibitors of aquaporins, particularly APQ1, have been reported primarily from Xenopus oocyte swelling assays, the activity of most has subsequently been disputed upon retesting using assays of water transport that are less prone to various artifacts [6] and they are therefore excluded from the tables [see Tradtrantipet al. (2017) [23] for a review].
\end{abstract}

\section{Contents}

This is a citation summary for Aquaporins in the Guide to Pharmacology database (GtoPdb). It exists purely as an adjunct to the database to facilitate the recognition of citations to and from the database by citation analyzers. Readers will almost certainly want to visit the relevant sections of the database which are given here under database links.

GtoPdb is an expert-driven guide to pharmacological targets and the substances that act on them. GtoPdb is a reference work which is most usefully represented as an on-line database. As in any publication this work should be appropriately cited, and the papers it cites should also be recognized. This document provides a citation for the relevant parts of the database, and also provides a reference list for the research cited by those parts.

Please note that the database version for the citations given in GtoPdb are to the most recent preceding version in which the family or its subfamilies and targets were substantially changed. The links below are to the current version. If you need to consult the cited version, rather than the most recent version, please contact the GtoPdb curators. 


\section{Database links}

Aquaporins

http://www.guidetopharmacology.org/GRAC/FamilyDisplayForward?familyld=119

Channels and Subunits

AQPO

http://www.guidetopharmacology.org/GRAC/ObjectDisplayForward?objectld=687 AQP1

http://www.guidetopharmacology.org/GRAC/ObjectDisplayForward?objectld=688 AQP2

http://www.guidetopharmacology.org/GRAC/ObjectDisplayForward?objectld=689 AQP3

http://www.guidetopharmacology.org/GRAC/ObjectDisplayForward?objectld=690 AQP4

http://www.guidetopharmacology.org/GRAC/ObjectDisplayForward?objectld=691 AQP5

http://www.guidetopharmacology.org/GRAC/ObjectDisplayForward?objectld=692 AQP6

http://www.guidetopharmacology.org/GRAC/ObjectDisplayForward?objectld=693 AQP7

http://www.guidetopharmacology.org/GRAC/ObjectDisplayForward?objectld=694 AQP8

http://www.guidetopharmacology.org/GRAC/ObjectDisplayForward?objectld=695 AQP9

http://www.guidetopharmacology.org/GRAC/ObjectDisplayForward?objectld=696 AQP10

http://www.guidetopharmacology.org/GRAC/ObjectDisplayForward?objectld=697 AQP11

http://www.guidetopharmacology.org/GRAC/ObjectDisplayForward?objectld=3062

\section{References}

1. Alexander SP, Kelly E, Marrion N, Peters JA, Benson HE, Faccenda E, Pawson AJ, Sharman JL, Southan C and Davies JA et al.. (2015) The Concise Guide to PHARMACOLOGY 2015/16: Other ion channels.Br. J. Pharmacol. 172: 5942-55 [PMID:26650442]

2. Alexander SP, Kelly E, Marrion NV, Peters JA, Faccenda E, Harding SD, Pawson AJ, Sharman JL, Southan C and Davies JA et al.. (2017) THE CONCISE GUIDE TO PHARMACOLOGY 2017/18: Other ion channels. Br. J. Pharmacol. 174 Suppl 1: S195-S207 [PMID:29055039]

3. Bienert GP and Chaumont F. (2014) Aquaporin-facilitated transmembrane diffusion of hydrogen peroxide. Biochim. Biophys. Acta 1840: 1596-604 [PMID:24060746]

4. Chow PH, Kourghi M, Pei JV, Nourmohammadi S and Yool AJ. (2020) 5-Hydroxymethyl-Furfural and Structurally Related Compounds Block the Ion Conductance in Human Aquaporin-1 Channels and Slow Cancer Cell Migration and Invasion. Mol. Pharmacol. 98: 38-48 [PMID:32434851]

5. Day RE, Kitchen P, Owen DS, Bland C, Marshall L, Conner AC, Bill RM and Conner MT. (2014) Human aquaporins: regulators of transcellular water flow. Biochim. Biophys. Acta 1840: 1492-506 [PMID:24090884]

6. Esteva-Font C, Jin BJ, Lee S, Phuan PW, Anderson MO and Verkman AS. (2016) Experimental Evaluation of Proposed Small-Molecule Inhibitors of Water Channel Aquaporin-1. Mol. Pharmacol. 89: 68693 [PMID:26993802]

7. Garneau AP, Carpentier GA, Marcoux AA, Frenette-Cotton R, Simard CF, Rémus-Borel W, Caron L, Jacob-Wagner M, Noël M and Powell JJ et al.. (2015) Aquaporins Mediate Silicon Transport in Humans. PLoS ONE 10: e0136149 [PMID:26313002]

8. Geyer RR, Musa-Aziz R, Qin X and Boron WF. (2013) Relative $\mathrm{CO}(2) / \mathrm{NH}(3)$ selectivities of mammalian aquaporins 0-9. Am. J. Physiol., Cell Physiol. 304: C985-94 [PMID:23485707]

9. Herrera M, Hong NJ and Garvin JL. (2006) Aquaporin-1 transports NO across cell membranes. Hypertension 48: 157-64 [PMID:16682607]

10. Holm LM, Jahn TP, Møller AL, Schjoerring JK, Ferri D, Klaerke DA and Zeuthen T. (2005) NH3 and NH4+ permeability in aquaporin-expressing Xenopus oocytes. Pflugers Arch. 450: 415-28 [PMID:15988592]

11. Holm LM, Klaerke DA and Zeuthen T. (2004) Aquaporin 6 is permeable to glycerol and urea Pflugers Arch. 448: 181-6 [PMID:14985982]

12. Ishibashi K, Kuwahara M, Gu Y, Kageyama Y, Tohsaka A, Suzuki F, Marumo F and Sasaki S. (1997) Cloning and functional expression of a new water channel abundantly expressed in the testis permeable to water, glycerol, and urea. J. Biol. Chem. 272: 20782-6 [PMID:9252401]

13. Ishibashi K, Morinaga T, Kuwahara M, Sasaki S and Imai M. (2002) Cloning and identification of a new member of water channel (AQP10) as an aquaglyceroporin. Biochim. Biophys. Acta 1576: 335-40 [PMID:12084581]

14. Ishibashi K, Tanaka $Y$ and Morishita Y. (2014) The role of mammalian superaquaporins inside the cell. 
Biochim. Biophys. Acta 1840: 1507-12 [PMID:24189537]

15. Kaldenhoff $R$, Kai $L$ and Uehlein N. (2014) Aquaporins and membrane diffusion of $\mathrm{CO} 2$ in living organisms. Biochim. Biophys. Acta 1840: 1592-5 [PMID:24141139]

16. Kitchen P, Day RE, Salman MM, Conner MT, Bill RM and Conner AC. (2015) Beyond water homeostasis: Diverse functional roles of mammalian aquaporins. Biochim. Biophys. Acta 1850: 2410-21 [PMID:26365508]

17. Kreida S and Törnroth-Horsefield S. (2015) Structural insights into aquaporin selectivity and regulation. Curr. Opin. Struct. Biol. 33: 126-34 [PMID:26342685]

18. Ma T, Yang B and Verkman AS. (1997) Cloning of a novel water and urea-permeable aquaporin from mouse expressed strongly in colon, placenta, liver, and heart. Biochem. Biophys. Res. Commun. 240: 3248 [PMID:9388476]

19. Madeira A, Fernández-Veledo S, Camps M, Zorzano A, Moura TF, Ceperuelo-Mallafré V, Vendrell J and Soveral G. (2014) Human aquaporin-11 is a water and glycerol channel and localizes in the vicinity of lipid droplets in human adipocytes. Obesity (Silver Spring) 22: 2010-7 [PMID:24845055]

20. Martins AP, Marrone A, Ciancetta A, Galán Cobo A, Echevarría M, Moura TF, Re N, Casini A and Soveral G. (2012) Targeting aquaporin function: potent inhibition of aquaglyceroporin-3 by a gold-based compound. PLoS ONE 7: e37435 [PMID:22624030]

21. Preston GM, Carroll TP, Guggino WB and Agre P. (1992) Appearance of water channels in Xenopus oocytes expressing red cell CHIP28 protein. Science 256: 385-7 [PMID:1373524]

22. Rambow J, Wu B, Rönfeldt $D$ and Beitz E. (2014) Aquaporins with anion/monocarboxylate permeability: mechanisms, relevance for pathogen-host interactions. Front Pharmacol 5: 199 [PMID:25225485]

23. Tradtrantip L, Jin BJ, Yao X, Anderson MO and Verkman AS. (2017) Aquaporin-Targeted Therapeutics: State-of-the-Field. Adv. Exp. Med. Biol. 969: 239-250 [PMID:28258578]

24. Verkman AS, Anderson MO and Papadopoulos MC. (2014) Aquaporins: important but elusive drug targets. Nat Rev Drug Discov 13: 259-77 [PMID:24625825]

25. Wang Y and Tajkhorshid E. (2010) Nitric oxide conduction by the brain aquaporin AQP4.Proteins 78: 66170 [PMID:19842162]

26. Watanabe S, Moniaga CS, Nielsen S and Hara-Chikuma M. (2016) Aquaporin-9 facilitates membrane transport of hydrogen peroxide in mammalian cells. Biochem. Biophys. Res. Commun. 471: 191-7 [PMID:26837049]

27. Yang B. (2017) Aquaporins In Advances in Experimental Medicine and Biology Edited by Yang B: Springer: 1-276 [ISBN: 9789402410570]

28. Yang B and Verkman AS. (1997) Water and glycerol permeabilities of aquaporins 1-5 and MIP determined quantitatively by expression of epitope-tagged constructs in Xenopus oocytes. J. Biol. Chem. 272: 16140-6 [PMID:9195910] 